\title{
CHOSEN ASPECTS OF LIFESTYLES OF PHYSICALLY ACTIVE WOMEN AGED 45-59 AND 60-74
}

\section{WYBRANE ASPEKTY STYLÓW ŻYCIA AKTYWNYCH FIZYCZNIE KOBIET W WIEKU 45-59 I 60-74 LAT}

\author{
Maria Alicja Nowak ${ }^{1(A, B, C, D, E, F)}$, Natalia Troczyńska ${ }^{2(B, F)}$, \\ Justyna Forjasz ${ }^{2(B, F)}$, Leonard Nowak ${ }^{2(A, D, G)}$ \\ ${ }^{1}$ University of Szczecin, Faculty of Physical Education and Health Promotion, Poland \\ ${ }^{2}$ University of Physical Education in Poznań, Department of Physical Culture in Gorzów Wielkopolski, Poland
}

Authors' contribution Wkład autorów: A. Study design/planning zaplanowanie badań B. Data collection/entry zebranie danych C. Data analysis/statistics dane - analiza i statystyki D. Data interpretation interpretacja danych E. Preparation of manuscript przygotowanie artykułu F. Literature analysis/search wyszukiwanie i analiza literatury G. Funds collection zebranie funduszy

Tables: 3

Figures: 2

References: 30

Submitted: 04.05.2016

Accepted: 09.06.2016

\begin{abstract}
Summary
Background. The aim of the study was to compare chosen aspects of lifestyle of women aged 45-59 and 60-74.

Material and methods. The study, carried out between 2013 and 2015, embraced 120 women who engaged in physical activity. Respondents were students of the University of the Third Age in Gorzów Wlkp. and the Elderly and Disabled Activation Center in Piła. Two age categories were distinguished: 45-59 and 60-74 years old. In the study a diagnostic survey was employed, with the use of the techniques of questionnaire, interview and observation. The qualitative and quantitative analysis was carried out with the employment of: frequency of characteristics, chi-squared independence test and multiple correspondence analysis.

Results. Older women far more often chose positive health behaviors than those under 60 years of age. There were more current nonsmokers among them, as well as nondrinkers or those who drank less frequently and controlled their health more often. Younger women assessed their own health and physical fitness higher. There were no obese people among the subjects.

Conclusions. There is a need for the dissemination of healthy lifestyle among people aged $60+$, especially in the situation of an aging population with unstable retirement age. Activation of people belonging to this age group is a chance to improve their life quality.
\end{abstract}

Keywords: physical activity, smoking, alcohol consumption, BMI, health and physical fitness self-evaluation

Streszczenie
Wprowadzenie. Celem pracy było porównanie wybranych aspektów stylu życia kobiet w wieku 45-59 lat i 60-74 lat.

Materiał i metody. Badaniami, w latach 2013-2015, objęto 120 kobiet podejmujących aktywność fizyczną. Respondentki były słuchaczkami Uniwersytetu Trzeciego Wieku w Gorzowie Wlkp. oraz Centrum Aktywizacji Osób Starszych i Niepełnosprawnych w Pile. Wyróżniono dwiekategorie wieku:45-59lat oraz 60-74 lata.Wbadaniach zastosowano metodę sondażu diagnostycznego z wykorzystaniem technik badawczych: kwestionariusza ankiety, wywiadu i obserwacji. Analizę jakościową i ilościową przeprowadzono stosując: frekwencję cech, test niezależności chi-kwadrat oraz wielowymiarową analizę korespondencji.

Wyniki. Kobiety w starszym wieku zdecydowanie częściej dokonywały wyboru pozytywnych zachowań zdrowotnych niż badane poniżej 60. roku życia. Wśród nich występowało więcej niepalących obecnie, niepijących lub pijących z mniejszą częstotliwością oraz kontrolujących częściej swoje zdrowie. Kobiety młodsze wyżej oceniały stan własnego zdrowia i sprawności fizycznej. Wśród badanych nie było osób otyłych.

Wnioski. Istnieje potrzeba upowszechniania prozdrowotnego stylu życia wśród osób w wieku 60 lat i więcej, zwłaszcza w sytuacji starzejącego się społeczeństwa i niestabilnego wieku emerytalnego. Aktywizacja osób należących do tej grupy wieku jest szansą na poprawę jakości ich życia.

Słowa kluczowe: aktywność fizyczna, palenie ty toniu, spoży wanie alkoholu, BMI, samoocena zdrowia i samoocena sprawności fizycznej

Nowak MA, Troczynska N, Forjasz J, Nowak L. Chosen aspects of lifestyles of physically active women aged 45-59 and 60-74. Health Problems of Civilization 2016; 10(3): 30-37. doi: 10.5114/hpc.2016.61364.

Address for correspondence / Adres korespondencyjny: Maria Alicja Nowak, University of Szczecin, Faculty of Physical Education and Health Promotion, Aleja Piastów 40b, 71-065 Szczecin, Poland, e-mail: maria-nowak@wp.pl, tel.: +48 9144427 33/34

Copyright: ( 2016 Pope John Paul II State School of Higher Education in Biała Podlaska. This is an Open Access journal, all articles are distributed under the terms of the Creative Commons Attribution-NonCommercial-ShareAlike 4.0 International (CC BY-NC-SA 4.0) License (http://creativecommons.org/licenses/by-nc-sa/4.0/), allowing third parties to copy and redistribute the material in any medium or format and to remix, transform, and build upon the material, provided the original work is properly cited and states its license. 


\section{Introduction}

Human life is subject to diverse periodization. The distinguishing of age categories is influenced by many factors, including: lengthening of people's life span, the development of civilization, the social and economic situation. These factors partially determine the pre-production, production and post-production phases. There are many different classifications of age categories. The WHO experts have identified: pre-old age (45-59 years old), early old age (60-74 years old), late old age (75-89 years old) and longevity (90 years old and above) [1].

Women's everyday lifestyle is determined by their responsibilities related to the family, home and career. Women aged 31-50 had relatively less time, as well as those who had children up to 15 years old. The older women's lifestyles were the most varied: some of them lived alone, others with husbands or partners, with adult children, grandchildren, sometimes in multi-generation families. The older subjects still worked intensively, did not work at all, were old age or ill-health pensioners. Their situation determined opportunities for physical activity [2].

Engaging in physical activity is characteristic of women who are younger and better educated, and have a good or a very good financial situation [3] also referred to as a higher level of income [4]. A lower level of physical activity is typical of less educated and older persons $[5,6]$. Recent research has shown that the declared level of physical activity of Polish society is not as low as it had been demonstrated in several studies [7]. In every single study, however, it was found that older people are less physically active in comparison with those under the age of 50, although there has been a slight increase in physical activity in this group, from $20.7 \%$ to $24.6 \%$ [4]. In the National Health Program for the years 2016-2020 (draft) [8] in the operational goals B and $\mathrm{C}$ attention is drawn to lifestyle factors: increasing physical activity of the population (including physical activation of elderly people) and limiting the spread of tobacco use and alcoholic beverages consumption, as well as preventing behavioral addictions. The results of scientific research show that physical activity undertaken by women has a beneficial effect on their implementation of other health promoting behaviors [9]. Appreciation of the importance of physical activity has an impact on the choices made about free time by adult women [10] and adolescents [11,12], as well as fostering recovery of health after lesions [13] or internal and external injuries suffered as a result of practicing sports [14]. By contrast, weight gain is associated to a large extent with e.g. deterioration of physical fitness, reduced prosperity and increased risk of disability caused by obesity [15]. It is usually linked to a shortage of physical activity.

In the concept of lifestyle self-evaluation plays an important role. High self-evaluation fosters health and encourages embracing new challenges associated with everyday life and self-realization. The value of health undergoes evolution among different age groups $[10,16]$.

Physical activity, smoking, alcohol consumption, BMI, health self-evaluation, physical fitness self-evaluation - they are lifestyle elements which affect healthy functioning of society. Their implementation is different among women and men, children and youth, and mature and elderly people.

In view of the above facts the aim of the study was to compare chosen aspects of lifestyle of women aged 4559 and 60-74.

The following hypotheses were formulated:

1. Women aged 45-59 undertook physical activity mainly in an organized form, while those aged 60-74 preferred also individual forms.

2. Choices of positive health behaviors are more common in older age.

3. Younger women have a higher health and physical fitness self-evaluation.

\section{Materials and methods of research}

\section{Materials of research}

The study included 120 women regularly engaging in physical activity. The respondents were students of the University of the Third Age in Gorzów Wlkp. and the Elderly and Disabled Activation Center in Piła, and attended fitness clubs. The subjects were divided into two age categories: 45-59 years old (38 persons) (preold age) and 60-74 (82 persons) (early old age). The respondents were mostly married women (63.9\%). Most often they had one child (51.7\%). There were more childless individuals among women aged 45-59 (34.2\%). The majority of women had a secondary education (52.6\%). The respondents were in the highest occupational categories: specialists (intellectuals and managers), and technical, administrative and office workers (35.3\% and $37.1 \%$ resp.) Craftswomen accounted for $12.9 \%$ and mental and mental-physical workers for $8.7 \%$. There were no women in the physical workers category. Women aged 45-59 were more often full-time and part-time employees. This group also included retirement and ill-health pensioners (12.1\%). About 95\% of those aged 60-74 were retired (1.2\% with ill-health pension). The subjects mostly had a good and a very good financial situation. None of them reported a bad or a very bad financial situation. 


\section{Methods of research}

A diagnostic survey was employed, with the use of the techniques of questionnaire, interview and observation. The qualitative and quantitative analysis was carried out with the employment of standard statistical methods: frequency of characteristics, chi-squared independence test and multiple correspondence analysis. These analyses are available in the statistical software package Statistica 12 [StatSoft, inc. 2015 Statistica for Windows]. For the correlations studied, statistical significance at the level of $\mathrm{p} \leq 0.05$ was assumed.

\section{Research results}

The relationships between the subjects' age and their marital status and education are presented in Table 1 .

Table 1. Social characteristics of the women studied (independence $\chi^{2}$ test)

\begin{tabular}{|c|c|c|c|c|c|c|}
\hline \multirow{3}{*}{ Specification } & \multicolumn{4}{|c|}{ Age categories (in years) } & \multirow{2}{*}{\multicolumn{2}{|c|}{ Total }} \\
\hline & \multicolumn{2}{|c|}{$45-59$} & \multicolumn{2}{|c|}{$60-74$} & & \\
\hline & $\mathbf{n}$ & $\%$ & $\mathbf{n}$ & $\%$ & $\mathbf{n}$ & $\%$ \\
\hline $\begin{array}{l}\text { Marital status* } \\
\text { - spinster } \\
\text { - married } \\
\text { - widow } \\
\text { - divorced }\end{array}$ & $\begin{array}{c}1 \\
32 \\
1 \\
3\end{array}$ & $\begin{array}{c}2.7 \\
86.5 \\
2.7 \\
8.1\end{array}$ & $\begin{array}{c}5 \\
44 \\
26 \\
7\end{array}$ & $\begin{array}{c}6.1 \\
53.7 \\
31.7 \\
8.5\end{array}$ & $\begin{array}{c}6 \\
76 \\
27 \\
10\end{array}$ & $\begin{array}{c}5.0 \\
63.9 \\
22.7 \\
8.4\end{array}$ \\
\hline $\begin{array}{l}\text { Education* } \\
\text { - pre-secondary } \\
\text { - secondary } \\
\text { - post-secondary }\end{array}$ & $\begin{array}{c}7 \\
14 \\
16\end{array}$ & $\begin{array}{l}18.9 \\
37.8 \\
43.2\end{array}$ & $\begin{array}{c}4 \\
47 \\
28\end{array}$ & $\begin{array}{c}5.1 \\
59.5 \\
35.4\end{array}$ & $\begin{array}{l}11 \\
61 \\
44\end{array}$ & $\begin{array}{r}9.5 \\
52.6 \\
37.9\end{array}$ \\
\hline
\end{tabular}

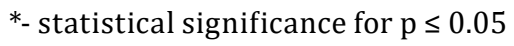

Married women dominated both age groups, but there were more of them in the younger one. In the older group more widows were observed (31.7\%) ( $\mathrm{p} \leq 0.05$ for the $\chi^{2}$ test). A statistically significant correlation was also found between age and education ( $\mathrm{p} \leq 0.05$ for the $\chi^{2}$ test). While the majority of women had a secondary education, the younger women more often had a post-secondary education $(43.2 \%)$

All the women took physical exercise in organized groups, once or twice a week, and some of them also individually. Most of the subjects (67.5\%) preferred exercise in a gymnasium (gymnastics, yoga, therapeutic dance, fitness) (Figure 1).

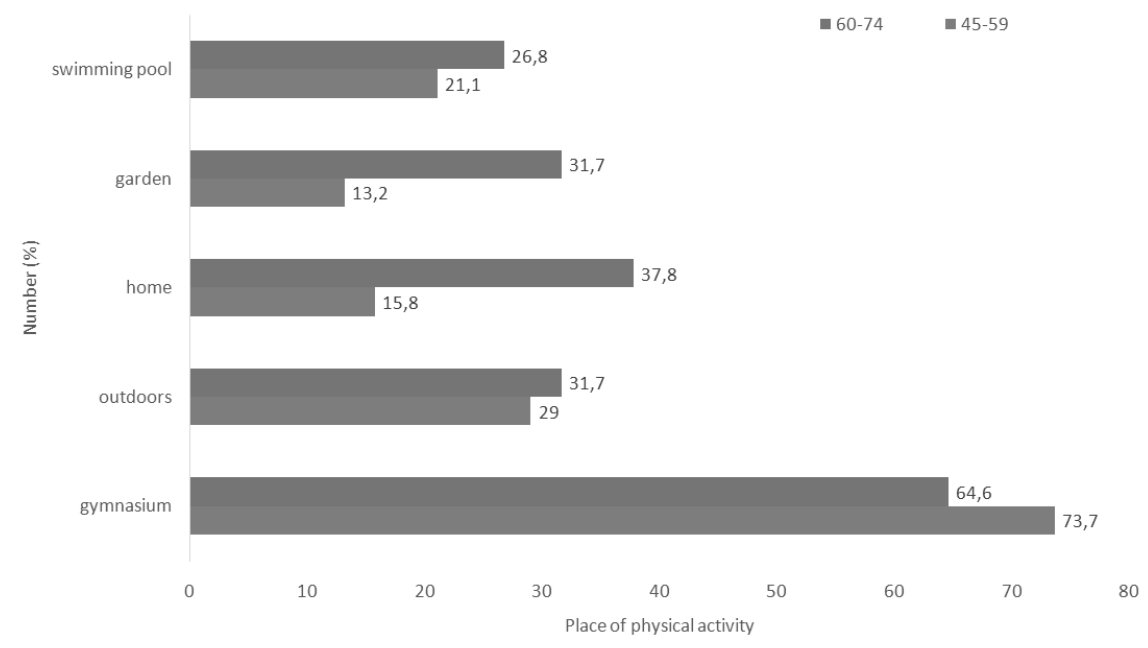

Figure 1. Places of women's physical activity

The older women, as compared to the younger, significantly more often exercised at home $(\mathrm{p} \leq 0.05$ for the $\chi^{2}$ test) and took care of gardens ( $\mathrm{p} \leq 0.05$ for the $\chi^{2}$ test). Some people $(30.8 \%)$ preferred outdoor activities (jogging and Nordic walking-in a group and individually) and swimming (25\%). No differences were observed concerning the subjects' age and practicing these forms of physical activity. 
Almost half of the respondents had proper body mass (47.3\%). The number of underweight subjects was slightly higher than the number of overweight ones, but the differences were not statistically significant (Table 2).

Table 2. Chosen health promoting behaviors of women aged 45-59 and 60-74 (independence $\chi^{2}$ test)

\begin{tabular}{|c|c|c|c|c|c|c|}
\hline \multirow{3}{*}{ Specification } & \multicolumn{4}{|c|}{ Age categories (in years) } & \multirow{2}{*}{\multicolumn{2}{|c|}{ Total }} \\
\hline & \multicolumn{2}{|c|}{$45-59$} & \multicolumn{2}{|c|}{$60-74$} & & \\
\hline & $\mathbf{n}$ & $\%$ & $\mathbf{n}$ & $\%$ & $\mathbf{n}$ & $\%$ \\
\hline $\begin{array}{l}\text { Nutritional status (BMI) } \\
\text { - underweight } \\
\text { - proper body mass } \\
\text { - overweight }\end{array}$ & $\begin{array}{l}5 \\
7 \\
4\end{array}$ & $\begin{array}{l}31.3 \\
43.7 \\
25.0\end{array}$ & $\begin{array}{l}22 \\
37 \\
18\end{array}$ & $\begin{array}{l}28.6 \\
48.0 \\
23.4\end{array}$ & $\begin{array}{l}27 \\
44 \\
22\end{array}$ & $\begin{array}{l}29.0 \\
47.3 \\
23.7\end{array}$ \\
\hline $\begin{array}{l}\text { Smoking (ever) } \\
\text { - yes } \\
\text { - no }\end{array}$ & $\begin{array}{l}14 \\
24 \\
\end{array}$ & $\begin{array}{l}36.8 \\
63.2\end{array}$ & $\begin{array}{l}38 \\
42 \\
\end{array}$ & $\begin{array}{l}47.5 \\
52.5\end{array}$ & $\begin{array}{l}52 \\
66\end{array}$ & $\begin{array}{l}44.1 \\
55.9 \\
\end{array}$ \\
\hline $\begin{array}{l}\text { Do you still smoke cigarettes?* } \\
\text { - yes } \\
\text { - no }\end{array}$ & $\begin{array}{c}5 \\
33\end{array}$ & $\begin{array}{l}13.2 \\
86.8\end{array}$ & $\begin{array}{c}2 \\
80\end{array}$ & $\begin{array}{c}2,4 \\
97.6\end{array}$ & $\begin{array}{c}7 \\
113\end{array}$ & $\begin{array}{c}5.8 \\
94.2\end{array}$ \\
\hline $\begin{array}{l}\text { Alcohol consumption frequency* } \\
\text { - I don't drink } \\
\text { - less often than once a month } \\
\text { - once or twice a month } \\
\text { - once or twice a week }\end{array}$ & $\begin{array}{c}3 \\
9 \\
17 \\
9\end{array}$ & $\begin{array}{c}7.9 \\
23.7 \\
44.7 \\
23.7\end{array}$ & $\begin{array}{c}16 \\
34 \\
25 \\
7 \\
\end{array}$ & $\begin{array}{c}19.5 \\
41.5 \\
30.5 \\
8.5\end{array}$ & $\begin{array}{l}19 \\
43 \\
42 \\
16\end{array}$ & $\begin{array}{l}15.8 \\
35.8 \\
35.0 \\
13.4\end{array}$ \\
\hline $\begin{array}{l}\text { Health checks } \\
\text { - breast* } \\
\text { - gynecological } \\
\text { - dental } \\
\text { - laboratory }\end{array}$ & $\begin{array}{l}19 \\
24 \\
24 \\
24\end{array}$ & $\begin{array}{l}51.4 \\
64.9 \\
64.9 \\
64.9\end{array}$ & $\begin{array}{l}52 \\
48 \\
55 \\
59\end{array}$ & $\begin{array}{l}73.2 \\
69.7 \\
71.4 \\
78.7\end{array}$ & $\begin{array}{l}71 \\
72 \\
79 \\
83\end{array}$ & $\begin{array}{l}65.7 \\
67.9 \\
69.3 \\
74.1\end{array}$ \\
\hline
\end{tabular}

*- statistical significance for $\mathrm{p} \leq 0.05$

$44.1 \%$ of the subjects declared smoking at any time in their lives. The older women slightly more often. Most of the women who had ever smoked did not do it any longer, and they were more often the older ones ( $p \leq 0.05$ for the $\chi^{2}$ test).

Over $70 \%$ of the subjects consumed alcohol less often than once a month or once or twice a month. The drinkers more often belonged to the younger group, as well as those who drank once or twice a week. The differences were not significant.

As far as health checks are concerned, over $65 \%$ of the respondents had undergone them in the previous year. In each case the older women more often reported having been to gynecological, dental (every six months), laboratory and breast (mammogram or ultrasound) checkups. With the last mention examination statistically significant differences have been found ( $\mathrm{p} \leq 0.05$ for the $\chi^{2}$ test).

Almost $90 \%$ of the respondents evaluated their own health as good or average (Table 3 ).

Table 3. Health and physical fitness self-evaluation of women aged 45-59 and 60-74 (independence $\chi^{2}$ test)

\begin{tabular}{|c|c|c|c|c|c|c|}
\hline \multirow{3}{*}{ Specification } & \multicolumn{4}{|c|}{ Age categories (in years) } & \multirow{2}{*}{\multicolumn{2}{|c|}{ Total }} \\
\hline & \multicolumn{2}{|c|}{$45-59$} & \multicolumn{2}{|c|}{$60-74$} & & \\
\hline & $\mathbf{n}$ & $\%$ & $\mathbf{n}$ & $\%$ & $\mathbf{n}$ & $\%$ \\
\hline $\begin{array}{l}\text { Health self-evaluation* } \\
\text { - very good } \\
\text { - good } \\
\text { - average } \\
\text { - bad } \\
\text { - I don't know }\end{array}$ & $\begin{array}{c}7 \\
19 \\
10 \\
1 \\
1\end{array}$ & $\begin{array}{c}18.4 \\
50.0 \\
26.4 \\
2.6 \\
2.6\end{array}$ & $\begin{array}{c}2 \\
38 \\
40 \\
1 \\
1\end{array}$ & $\begin{array}{c}2.4 \\
46.3 \\
48.7 \\
1.2 \\
1.2\end{array}$ & $\begin{array}{c}9 \\
57 \\
50 \\
2 \\
2 \\
\end{array}$ & $\begin{array}{c}7.5 \\
47.5 \\
41.6 \\
1.7 \\
1.7\end{array}$ \\
\hline $\begin{array}{l}\text { Physical fitness self-evaluation } \\
\text { - very high or high } \\
\text { - average } \\
\text { - low } \\
\text { - I don't know }\end{array}$ & $\begin{array}{c}10 \\
22 \\
3 \\
3\end{array}$ & $\begin{array}{c}26.3 \\
57.9 \\
7.9 \\
7.9\end{array}$ & $\begin{array}{c}17 \\
56 \\
6 \\
3\end{array}$ & $\begin{array}{c}20.7 \\
68.3 \\
7.3 \\
3.7\end{array}$ & $\begin{array}{c}27 \\
78 \\
9 \\
6\end{array}$ & $\begin{array}{c}22.5 \\
65.0 \\
7.5 \\
5.0\end{array}$ \\
\hline
\end{tabular}

*- statistical significance for $\mathrm{p} \leq 0.05$ 
Among the younger subjects very good and good health self-evaluations were more common, whereas among the older ones good and average ( $\mathrm{p} \leq 0.05$ for the $\chi^{2}$ test).

$22.5 \%$ of the subjects had a very high or high physical fitness self-evaluation. The younger women rated the level of their fitness as high more often, while the older ones as average, but the differences were insignificant.

Self-evaluation of health and physical fitness in comparison with the subjects' peers was also performed. $41.2 \%$ of the women thought their own health was better, $53.8 \%$ that it was the same and $5 \%$ that it was worse. A very similar situation was observed in comparisons of physical fitness self-evaluation with peers. The differences were not statistically significant.

Relationships between the women's age and their preferred health promoting behaviors in the context of their social situation were presented in a complex form based on multiple correspondence analysis (MCA) (Figure 2) in connection with the results of the chi-squared independence test (Tables 1, 2 and 3).

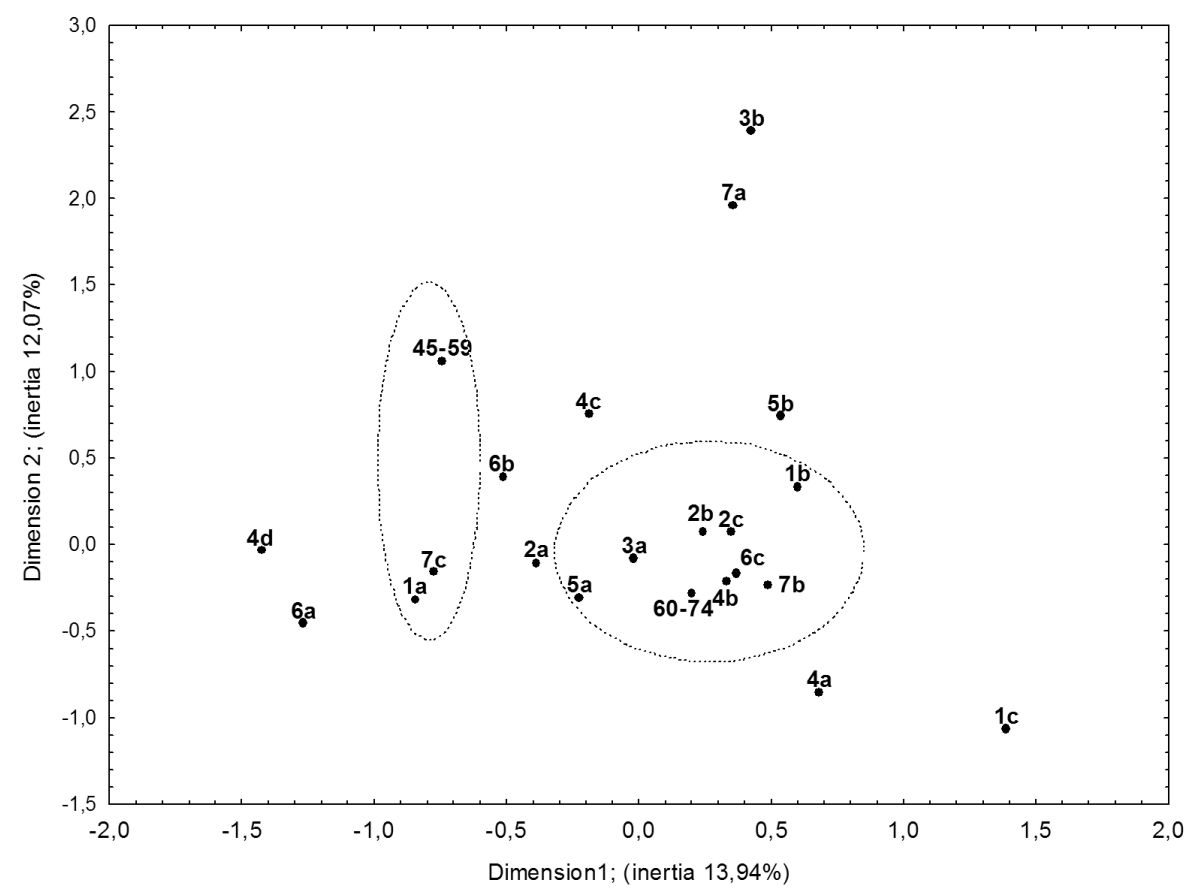

Figure 2. Relationships between the age and women's health promoting behaviors

Out of all the characteristics two dimensions (the first and the second) were selected for analysis. These dimensions explained $26.01 \%$ of the total $\chi^{2}$ value.

In conducting the graphical analysis of the results of the correspondence analysis in respect to the two dimensions in space, two groups were distinguished. The first one included women aged 45-59, with postsecondary education and a high physical fitness self-evaluation (1a). The second group included women aged 6074 . These persons were characterized by a good and average health self-evaluation $(2 \mathrm{~b}, 2 \mathrm{c})$, consumed alcohol less often than once a month (4b) and underwent breast checks (5a). Women aged 60-74 had more frequently smoked cigarettes in the past (3a), but had now mostly abandoned this habit (Table 2). Overweight persons were also observed (6c). This group was characterized by a secondary education.

Varied behaviors were characteristic of those who rated their health as very good (2a), did not drink or drank once or twice a month (4a, 4c), had not undergone breast checks in the last year (5b) and had normal body mass (6b).

The peripheral location was occupied by subjects with a pre-secondary education (7a), smoking (3b), assessing their physical fitness as low (1c), consuming alcohol once or twice a week (4d) and underweight (6a).

\section{Discussion}

The problem of discrepancies between the declared and the actual physical activity has been pointed out in a number of studies $[10,17]$. In the present study this situation was avoided, because all the respondents participated in organized forms of physical activity and they handed the questionnaires at the places where they took exercise. The subjects, however, declared additional physical activity (gymnastics at home, walking, 
gardening). These behaviors can stem from a reluctance to leave home, feeling awkward when performing certain exercises, but also from a variety of duties which aging people who do not have all their time for themselves have to cope with. Polish people are physically active in the open air and in their homes. Far fewer people use sports infrastructure [18]. Behaviors of the older women (60-74 years old), despite their attendance in organized classes, are similar to the behaviors of the whole Polish population. These subjects took exercise at home and were physically active in their gardens. The hypothesis that women aged 45-59 engaged in physical activity mainly in organized forms, while the older ones preferred individual forms was confirmed.

Among the beneficial effects of physical activity, a reduced risk of metabolic diseases should be emphasized, including obesity and diabetes $[19,20]$. In this study, involving physically active women, there were no obese people. Almost half of the respondents had normal body mass. The positive effect of regular physical activity on BMI was confirmed in research involving people aged 20-75: with the increase in the length of subjects' physical activity history the number of people with normal body mass rose [10]. In the light of the EHIS [21] 46\% of adult women are overweight. In this study such individuals accounted for $23.7 \%$. The literature also indicates that achieving the proper body mass is influenced by several factors [22], but physical activity is a necessary condition, which confirms the hypothesis assumed.

The results of a long-term study of a group of Australian elderly women indicate that the adoption of a healthier lifestyle through the use of an appropriate daily dose of physical activity and not smoking, is beneficial even for people of advanced age [23]. Similarly, in Polish studies, the rate of health behaviors (IZZ-Inventory of Health Behaviors) was found to increase with age. This rate was lower among physically inactive students of the UTA [24]. According to other studies carried out with the same method, the higher the education the greater the intensity of health behaviors [25].

In the light of the results of the European Health Interview Survey regarding Poles [21], smoking is gradually becoming less popular. Tobacco in various forms is smoked every day by $17 \%$ of adult women (in 2009 it was $18 \%$ of women). The smoking habit concerns $27 \%$ of women aged 50-59. In 2014 nonsmoking women accounted for $79.7 \%$, whereas in this study $94.2 \%$ of the respondents aged $45-74$ who engaged in physical activity declared that they did not smoke, despite prior yielding to this addiction. According to the WHO data, in the last 30 years there has been a gradual decline in tobacco consumption in Poland [8]. Relationships between the length of subjects' history of recreational physical activity and reduced tobacco use were also confirmed [10].

According to research, the proportion of women consuming alcohol decreased from approximately $66 \%$ in 2009 to $63 \%$ in 2014. Every 7th woman who drank alcohol admitted doing it at least once a week [21]. Among women with a long history of physical activity there is a tendency to prefer low-alcohol beverages, despite a fairly high frequency of their consumption [10].

There has been a considerable increase in the number of women undergoing mammograms. Almost $70 \%$ of women surveyed had been to the control examination, partly within the free breast screening program [21]. A similar number of respondents in this study (65.7\%) had had this examination, but much more often the older ones in comparison with those aged 45-59. The hypothesis that the choices of positive health behaviors are more common in old age was confirmed.

The functioning of the body in old age and the phenomenon of so called successful aging are influenced by physical activity. Persons who exercise regularly declare a higher subjective assessment of their health, feel better both in physical and mental terms, take up more beneficial health behaviors and enjoy a better quality of life $[10,26,27]$.

The survey health studies conducted by the Central Statistical Office [28] show that the health of adult Poles is steadily improving, but this subjective evaluation is much worse in comparison with their peers living in other European countries, particularly with regard to older people. Among 32 countries classified in terms of health self-evaluation, older Poles rank the 4 th worst place (before the inhabitants of Hungary, Latvia and Lithuania). A slight improvement of health self-evaluation was observed in the EHIS in 2014, but this change was not uniform. In the Lubuskie Province, compared with the previous survey in 2009, far fewer people rated their health as very good [21]. The association between health self-evaluation and physical activity was emphasized in studies of adults and the elderly [10, 27, 29].

To sum up, positive changes should be expected in the health of women aged 45-59 who practice a healthy lifestyle. At the same time there is a need for the dissemination of healthy lifestyle among people aged 60+, especially in the situation of an aging population with unstable retirement age. Activation of people belonging to this age group is a chance to improve their life quality [30]. 


\section{Conclusions}

1. Women aged 45-59 undertook physical activity mainly in an organized form, while those aged 60-74 preferred also individual forms.

2. Choices of positive health behaviors are more common for persons in older age. Among women aged 6074 there were more current nonsmokers, as well as nondrinkers or those who drank less frequently and controlled their health more often (especially breast checks).

3. The younger women assessed their health and physical fitness higher.

4. There were no obese women among the subjects.

\section{References:}

1. Zych AA. Słownik gerontologii społecznej. Warszawa: Wydaw. Akad. „Żak”; 2001 (in Polish).

2. Badanie uwarunkowań do podejmowania aktywności fizycznej osób starszych. Projekt zrealizowany metodą zogniskowanych wywiadów grupowych. MSiT, GfK Polonia Sp. z o.o. [Internet]. 15 Dec 2015. [cited 2016 Feb 10]. Available from: http://www.msport.gov.pl/badania-i-analizy/aktywnosc-fizyczna-spoleczenstwa (in Polish).

3. Nowak MA, Nowak L. Socio-demographic conditions of the realization of health-oriented lifestyles by women. Arch Budo 2013; 9(1): 29-37.

4. Uczestnictwo Polaków w sporcie i rekreacji ruchowej w 2012 r. GUS. Warszawa: ZWS; 2013. [Internet]. [cited 2016 Feb 14]. Available from: http://www.stat.gov.pl/ (in Polish).

5. Drygas W, Kwaśniewska M, Kaleta D, Pikala M, Bielecki W, Głuszek J, et al. Epidemiology of physical inactivity in Poland: prevalence and determinants in a former communist country in socioeconomic transition. Public Health 2009; 123(9): 592-7.

6. Sigmundová D, Sigmund E, Hamřík Z, Kalman M, Pavelka J, Frömel K. Sedentary behaviour and physical activity of randomised sample of Czech adults aged 20-64 years: IPAQ and GPAQ studies between 2002 and 2011. Cent Eur J Public Health. 2015; 23: 91-96.

7. Piątkowska M. Self-rated physical activity across Europe - Poland and other European countries. Biol Sport. $2012 ; 29(1): 23-31$.

8. NPZ na lata 2016-2020. [cited 2016 March 2]. Available from: www.legislacja.gov.pl/.../dokument164277.pdf.

9. Nowak MA. Physical Activity and its Associations with other Lifestyle Elements in Polish Women. Journal of Human Kinetics. 2011; Vol. 29: 161-172.

10. Nowak M. Aktywność fizyczna w prozdrowotnym stylu życia kobiet. Poznań: Akademia Wychowania Fizycznego; 2008 (in Polish).

11. Łubkowska W, Zdeb T, Mroczek B. Ocena ukształtowania fizjologicznych krzywizn kręgosłupa dziewcząt trenujących sport pływacki i nie uprawiających pływania. Family Medicine \& Primary Care Review. 2015; 17(3): 189-192 (in Polish).

12. Bergier J, Niźnikowska E, Bergier B, Junger J, Ács P, Salonna F. Diversity of physical activity among the school youth depending on the type of place of residence. Health Problems of Civilization. 2016; 10(1): 24-31.

13. Kotarska K, Wunsch E, Raszeja-Wyszomirska J, Kempińska-Podhorodecka A, Wójcicki M, Milkiewicz P. Leisure time physical activity and health-related behaviors after liver transplantation: a prospective, single centre study. Gastroenterology Review. 2015; 2, 1-5.

14. Stępień-Słodkowska M, Ficek K, Kaczmarczyk M, Maciejewska-Karłowska A, Sawczuk M, Eider J, et al. The Influence of biological factors on the injuries occurrence in the Polish population. Annals Agriculture and Environmental Medicine. 2016; vol. 23, 2: 316-319.

15. Wolin KY, Glynn RJ, Colditz GA, Lee IM, Kawachi I. Long-Term Physical Activity Patterns and Health-Related Quality of Life in U.S. Women. Am J Prev Med. 2007; June 1; 32(6):490-499.

16. Młynarska M, Rudnicka-Drożak E, Nowicki G, Misztal-Okońska P, Dyndur J, Majcher P. The concept of health in the opinion of people over 65 years of age. Gerontologia Polska. 2015; 1: 11-18 (in Polish).

17. Drygas W, Kwaśniewska M, Szcześniewska D, Kozakiewicz K, Głuszek J, Wiercińska E. et al. Ocena aktywności fizycznej dorosłej populacji Polski. Wyniki programu WOBASZ. Kardiologia Polska. 2005; 63 (supl. 4): 665669 (in Polish).

18. Sport i Rekreacja: Ogólnopolskie Badanie Polaków. Raport. Warszawa: MSiT. 2013. [Internet]. [cited 2016 March 2]. Available from: http://ps2012.pl/publikacje/raporty/19-moje-boisko-orlik-2012-szansa-rozwojuaktywnosci-spolecznej. 
19. Drygas W, Kostka T, Jegier A, Bednarek-Gejo A, Kwaśniewska M. Long-term effects of various physical activity levels in preventing obesity and metabolic syndrome in middle-aged men. Eur J Cardiovasc Prev Rehab. 2005; 12: 283-284.

20. Sygit K. Fundamental Significance of Physical Activity for Seniors' Health. Central European Journal of Sport Sciences and Medicine. 2015; 12 (4): 53-59.

21. Zdrowie i zachowanie zdrowotne mieszkańców Polski w świetle badania EHIS 2014 r. Warszawa: GUS. 2015. [Internet]. 2015 grudzień. [Cited 2016 Apr 16]. Available from: _http://stat.gov.pl/obszary-tematyczne/ zdrowie/.

22. Wenche DB, Holmen J, Krüger $\emptyset$, Midthjell K. Leisure time physical activity and change in body mass index: an 11-year follow-up study of 9357 normal weight health women 20-49 years old. J Womens Health (Larchmt). 2004 Jan-Feb;13(1):55-62.

23. Ford J, Spallek M, Dobson A. Self-rated health and a healthy lifestyle are the most important predictors of survival in elderly women. Age and Ageing. 2008; 37: 194-200.

24. Kozieł D, Kaczmarczyk M, Naszydłowska E, Gałuszka R. Wpływ kształcenia w Uniwersytecie Trzeciego Wieku na zachowania zdrowotne ludzi starszych. Studia Medyczne. 2008;12: 23-28.

25. Sygit-Kowalkowska E. The health behaviour of people in late adulthood-sociodemographic correlations and differences between social environments. Annales Academiae Medicae Stetinensis. 2013; 59 (1): $103-113$ (in Polish).

26. Rowiński R, Dąbrowski A. Aktywność fizyczna Polaków w wieku podeszłym. In: Mossakowska M, Więcek A, Błędowski P. editors. Aspekty medyczne, psychologiczne, socjologiczne i ekonomiczne starzenia się ludzi w Polsce. Poznań: Wydawnictwo Medyczne Termedia; 2012: 531-548 (in Polish).

27. Kaleta D, Jegier A. Rekreacyjna aktywność ruchowa a subiektywna ocena stanu zdrowia dorosłych osób. Pol. Arch. Med. Wew. 2004; 5:537-545.

28. Sytuacja demograficzna osób starszych i konsekwencje starzenia się ludności Polski w świetle prognozy na lata 2014-2050. Warszawa: GUS; 2014.

29. Knapik A, Rottermund J, Myśliwiec A, Plinta R, Gruca M. Aktywność fizyczna a samoocena zdrowia osób w starszym wieku. Przegląd Medyczny Uniwersytetu Rzeszowskiego i Narodowego Instytutu Leków w Warszawie. Rzeszów: 2011; 2, 195-204.

30. Markiewicz E, Skawina I. The political orientation of the State in terms of ageing societies. Gerontologia Polska. 2015: 1: 34-40. 